Federal Reserve Bank of Minneapolis

Research Department Staff Report 246

Revised May 1998

\title{
The Demand for Money and the Nonneutrality of Money
}

\author{
Harold L. Cole*
}

Federal Reserve Bank of Minneapolis

Lee E. Ohanian*

University of Minnesota

and Federal Reserve Bank of Minneapolis

\begin{abstract}
Many economists have worried about changes in the demand for money, since money demand shocks can affect output variability and have implications for monetary policy. This paper studies the theoretical implications of changes in money demand for the nonneutrality of money in the limited participation (liquidity) model and the predetermined (sticky) price model. In the liquidity model, we find that an important connection exists between the nonneutrality of money and the relative money demands of households and firms. This model predicts that the real effect of a money shock rose by 100 percent between 1952 and 1980 , and subsequently declined 65 percent. In contrast, we find that the nonneutrality of money in the sticky price model is invariant to changes in money demands or other monetary factors. Several researchers have concluded from VAR analyses that the effects of money shock over time are roughly stable. This view is consistent with the predictions of the sticky price model, but is harder to reconcile with the specific pattern of time variation predicted by the liquidity model.
\end{abstract}

${ }^{*}$ We thank Andy Atkeson, V.V. Chari, Larry Christiano, Anil Kashyap, Patrick Kehoe, Narayana Kocherlakota, Robert Lucas, Ed Prescott, Tom Sargent, Chris Sims, Nancy Stokey, and John Taylor for helpful comments and criticism. The views expressed herein are those of the authors and not necessarily those of the Federal Reserve Bank of Minneapolis or the Federal Reserve System. 


\section{Introduction}

Over the postwar period, there have been large changes in the velocity of money and correspondingly, the stock of money held by households and firms relative to output. These changes have led many economists to worry about the stability of money demand because it has implications for the relationship between money and aggregate variables like output, prices, and interest rates and also because money demand shocks can be a source of output variability and affect stabilization policy. In the basic IS-LM model, money demand shocks can affect the position of the LM curve, which can change aggregate demand and output, and consequently, can affect the impact of monetary policy. ${ }^{1}$ Little is known, however, about how shifts in money demand, or changes in the quantity of money demanded, affect the impact of monetary policy or the relationship between money and aggregate variables in general equilibrium monetary business cycle models.

One way the effect of monetary policy may change in these models is if a connection exists between the nonneutrality of money and the transactions demand for money. In this paper, we analyze this connection in the two most widely used general equilibrium monetary business cycle models in which monetary policy can have important effects: the sticky price model, in which money is nonneutral due to goods market frictions, and the limited participation (liquidity) model, in which money is nonneutral due to asset market frictions. We study how factors that are widely believed to have affected money demand over the postwar period, such as changes in monetary policy and transactions technologies, affect the nonneutrality of money in both models. We assess how the nonneutrality of money has changed over the postwar period as a consequence of observed changes in money holdings of firms and households. We find that the effect of changes in money demand on the nonneutrality of money depends critically on the source of nonneutrality, and consequently, the effects of changes in money demand are very different in these two models.

\footnotetext{
${ }^{1}$ There is a considerable empirical literature on the stability of money demand in the postwar United States. Judd and Scadding (1982) and Goldfeld and Sichel (1990) survey this literature and discuss the importance of changes in the demand for money for the relationship between money and aggregate variables and for the conduct of macroeconomic policy. By changing the relationship between money and other aggregate variables, variations in money demand can affect the ability of the Federal Reserve to target nominal measures such as nominal GNP or a price level. These issues, and the importance of monetary targeting of nominal variables, are discussed in Hall and Mankiw (1994).
} 
In the liquidity model, there is a key connection between the transactions demand for money and the nonneutrality of money that involves the relative money demands of households and firms. We show analytically for a particular version of this model, and by simulation methods for general versions, that there is a linear relationship between the real effect of a money shock and the ratio of money held by households to money held by firms. If this ratio doubles, the effect of an unexpected money shock on output also doubles. This linear dependence arises whether compositional shifts are due to changes in government policies or changes in transactions technologies. We find that this sensitivity is due to the fact that the nonneutrality of money in this model is fundamentally tied to money's role as a medium of exchange.

Given the recent growth in the use of credit cards, electronic money, store-in-value cards, and other forms of payment, some observers have concluded that money's medium of exchange role has been declining and have asked how these developments have changed the impact of monetary policy. This model predicts that if money's medium of exchange role were to continue to decline, the nonneutrality of money and the impact of monetary policy would be unaffected only if the composition of money demand is unchanged.

A very different connection exists between money's medium of exchange role and the nonneutrality of money in the sticky price model, reflecting an interaction between pricesetting and the transactions demand for money. Theoretically, we find that factors that shift the money demand function for either households or firms, or that result in movements along these demand curves, can affect the nonneutrality of money in this model. However, this connection is quantitatively important only if the interest elasticity of money demand is close to zero. If money demand is plausibly elastic, we find that the nonneutrality of money in this model is invariant to monetary factors. This model predicts that continued declines in money's use as a medium of exchange would not affect the impact of monetary policy. The invariance in this model arises because the key role of money in this model is not its medium of exchange function, but rather its unit of account function: prices are set in advance and are denominated in currency units. ${ }^{2}$

\footnotetext{
${ }^{2}$ Michael Woodford (1997) has argued theoretically that it is feasible to evaluate monetary policy in environments in which money disappears from the economy. Our analysis indicates that the standard sticky
} 
If the composition of money holdings between households and firms has been stable over time, both theoretical models predict that the effects of a money shock have been stable over time. However, if the composition has changed, the models have very different predictions: the sticky price model predicts stability, while the liquidity model predicts that the real effect of a money shock moves in lockstep with the ratio of household to firm money holdings. We present postwar U.S. data on the composition of money holdings that show large changes in the ratio of money held by households to money held by firms over the postwar period. This ratio rose 100 percent between 1950 and 1980 and has declined about 65 percent over the last 20 years. These changes imply correspondingly large swings in the real effects of a money shock in the liquidity model in the postwar United States.

We use these very different predictions to provide a theoretical interpretation of the empirical literature that has studied the stability of the effects of money shocks. Several researchers in this literature have concluded that the effects of money shocks have been roughly stable over time. This view is consistent with the predictions of the sticky price model, but is more difficult to reconcile with the liquidity model, which predicts significant instability in the effect of a money shock over time. Thus, our analysis points to imperfect price adjustment, rather than the financial frictions associated with the liquidity model, as the main factor responsible for the nonneutrality of unexpected money in the postwar United States.

The paper is organized as follows. Section 2 presents the basic environment that is used to develop the liquidity model in Section 3 and the sticky price model in Section 4 . In Section 5, we linearize both models to gain a basic understanding of how money affects output. In Section 6, we present postwar data on velocity and the composition of money demand between firms and households. In Section 7, we calibrate both models to capture these postwar changes in velocity and the composition of money holdings, and we use the calibrated models to theoretically assess how the nonneutrality of money has changed in the postwar United States. In Section 8, we discuss the implications of our findings for empirical studies of the real effects of money shocks. Section 9 presents a summary and conclusion.

price model is one environment in which this seems to be true. 


\section{The Basic Environment}

Before specifying the liquidity and sticky price models, we present the basic environment that is the foundation of both models. This environment is the same as the standard one used in the monetary business cycle literature with one modification: firms, as well as households, have an interest elastic demand for money. This allows us to study in a symmetric fashion the effects of changes in money demand brought about by changes in household or firm behavior.

Households are identical and have standard time separable preferences. The household's preferences over a CES aggregator of consumption, $c_{t}$, and the total level of labor effort, $l_{t}$, are given by

$$
E \sum_{t=0}^{\infty} \beta^{t} u\left(c_{t}, l_{t}\right)
$$

where

$$
c_{t}=\left[\int c_{t}(i)^{\theta} d i\right]^{1 / \theta}
$$

and $c_{t}(i)$ denotes households' consumption of good $i$ in period $t$. This Dixit-Stiglitz preference specification over a continuum of final goods is standard in the sticky price literature.

We assume that households sell intermediate goods to firms and that firms sell final goods to households. There is a continuum of intermediate goods indexed on the unit interval. Households produce intermediate goods using a backyard constant returns to scale technology in which one unit of labor produces one unit of the intermediate good. To introduce an interest elastic demand for money for both households and firms, we use the cash/credit goods construct of Lucas and Stokey (1987) in which cash sales result in currency receipts that accumulate during the period for the sellers, while credit sales result in invoices that are settled at the start of the next period.

For households, we assume that the fraction $\gamma$ of the unit interval of final goods must be purchased with cash, while the remainder of the final goods can be purchased with credit. Cash final goods are indexed by $i \in[0, \gamma]$, and credit goods are indexed by $i \in(\gamma, 1]$. Variations in this parameter will change the demand for money by households and consequently change velocity. Similarly, for firms, we assume that the fraction $\eta$ of the unit interval of intermediate goods must be purchased with cash, while the remainder of the intermediate goods can be 
purchased with credit. Cash intermediate goods are indexed by $j \in[0, \eta]$, and credit goods are indexed by $j \in(\eta, 1]$. Variations in this parameter will change the demand for money by firms.

At the start of the period, households must allocate their total money balances $(\Omega)$ between cash used to buy consumption in the subsequent goods market $(m)$ and cash used to buy securities in the asset market $(n)$, where

\section{(1) $\Omega \geq n+m$.}

When households enter the asset market, they receive a nominal transfer $T$ from the government, which, along with their $n$ units of money, is used to make loans and to buy state contingent securities. We let $b$ denote the quantity of noncontingent bonds purchased and $R$ denote those bonds' gross return. We let $q\left(s^{\prime}\right)$ denote the quantity of the state-contingent bonds purchased in the period and $Q\left(s^{\prime}\right)$ denote the price in the period of a state-contingent (discount) bond which pays one unit of output in the next period if the state is $s^{\prime}$. In making its security purchases, the household faces the constraint

$$
n+T \geq b+\sum_{s^{\prime}} q\left(s^{\prime}\right) Q\left(s^{\prime}\right) .
$$

Since households are free to produce any of the intermediate inputs, production arbitrage implies that the prices of all intermediate goods will be the same, and we denote this price by $w$. The household's nominal wealth next period is given by

$$
\Omega^{\prime}=\Pi+w l-\int_{0}^{1} p(i) c(i) d i+m+(R-1) b+n+T+q\left(s^{\prime}\right)
$$

where $\Pi$ denotes profits from firms and $w l$ is the revenue from the sale of intermediate goods.

After transacting in the asset market, households enter the goods market. The cashin-advance (CIA) constraint for the household in this market is

$$
\text { (4) } \quad m \geq \int_{0}^{\gamma} p(i) c(i) d i .
$$

Firms purchase intermediate goods from households. Households are free to produce any of these intermediate goods. The final goods production technology is operated by firms, 
which are owned by households. Firms seek to maximize period profits, (П), which are distributed to the households. The production technology for final good $i$ is given by

$$
y(i)=\left(\int_{0}^{1} x(j)^{\psi} d j\right)^{\frac{1}{\psi}}
$$

where $x(j)$ is the quantity of intermediate good $j$ used. This is a standard Dixit-StiglitzEthier technology, with elasticity of substitution $\frac{1}{1-\psi}$.

Since the fraction $\eta$ of the unit interval of intermediate goods must be purchased with cash, the firm faces the CIA constraint

$$
B \geq \int_{0}^{\eta} w(j) x(j) d j
$$

where $w(j)$ denotes the price of intermediate good $j$, and $B$ denotes the funds that the firms have borrowed in the asset market. Given free entry in the production of intermediate goods, all intermediate goods sell for the same price. ${ }^{3}$

The government is represented by a monetary policy rule by which the government injects and removes cash through lump-sum taxes or transfers. Transfers are given by $T_{t}=$ $\left(g_{t}-1\right) M_{t}$, where $g_{t}$ is the stochastic growth rate of money and $M_{t}$ is the beginning-of-period level of the money stock.

\section{The Liquidity Model}

Our liquidity model is very similar to the representative agent models used by Lucas (1990), Christiano (1991), Fuerst (1992, 1994), Christiano and Eichenbaum (1992), Schlagenhauf and Wrase (1995), and King and Watson (1996). Other important (nonrepresentative agent) contributions in this literature include those of Grossman and Weiss (1983) and

\footnotetext{
${ }^{3}$ The environment that we consider is general enough that it can be interpreted as one in which households hold real balances because they provide utility (money in the utility function), and firms hold real balances because they facilitate production (money in the production function). Under this interpretation, final goods are produced with labor and real balances. If we denote the firm's real balances per worker's wage by $B^{*}=B / w l$, then the firm's output is given by $y(i)=A\left(B^{*}\right) l$, where

$$
A\left(B^{*}\right)=\left[\left(B^{*}\right)^{\psi}+\left(1-B^{*}\right)^{\psi}\right]^{\frac{1}{\psi}} .
$$

Similarly, if the prices of all the consumption goods are equal to $p$ and we define real balances per unit of consumption as $m^{*}=m / p c$, then we can interpret the cash/credit good distinction for the household as a situation in which consumption is produced with units of the output good and money, $c=A\left(m^{*}\right) E$, where $E$ is just the number of units of the output good.
} 
Rotemberg (1984), which have been recently extended to open economy models by Alvarez and Atkeson (1997). The limited participation framework has become widely used because it provides a tractable general equilibrium model in which increases in nominal money lead to lower interest rates and higher output.

The basic model works as follows: households allocate their wealth between cash that can be used to purchase goods and deposits with an intermediary that are loaned to firms. This allocation is made prior to the realization of the money shock. The intermediary makes loans to firms, who use the cash to purchase inputs. Funds available for loans are household deposits, plus the monetary transfer. If the transfer is positive, loanable funds rise, and to induce firms to increase borrowing and increase production, the interest rate must fall.

To develop the liquidity model, we simply make two modifications to our basic environment. As is standard, we assume that the household's portfolio decision is made before the realization of the money shock. In earlier versions of these models without firm interest elastic money demand, such as Christiano and Eichenbaum (1992), this modification is sufficient to generate a liquidity effect. In our model with firm interest elastic money demand, however, we also need to restrict the short-run elasticity of substitution in production between cash and credit inputs to generate a liquidity effect. We discuss this in detail below.

\section{A. The Firm's Problem}

Because firms are free to produce any type of good with the same production function, the price of the final goods must be the same, and we will denote the price simply by $p$. Once firm interest elastic money demand is introduced into the standard liquidity model, we find that an increase in the money supply does not generate a liquidity effect (an increase in output) for all parameter values. To guarantee a liquidity effect in this model, we find that we must alter the firm's problem in hiring inputs. The simplest modification we found to work is for the firm to choose its factor ratio before the realization of the money shock. After the realization of the money shock, the firm chooses its overall scale of operation by hiring factors according to the predetermined proportions. This ex post Leontieff technology preserves the liquidity effect, since increasing production requires increasing both cash and 
credit intermediate inputs. ${ }^{4}$

We assume that firms behave competitively. The concavity of the production function implies that quantities of all cash inputs are the same, as are the quantities of all credit goods inputs. We denote the inputs simply by $x_{1 i}$ and $x_{2 i}$, respectively, where $i=1$ denotes cash goods and $i=2$ denotes credit goods. Given this ratio of cash to credit inputs, we denote the overall scale of operation by $\varepsilon_{i}$. With this notation, the static problem of a firm is

$$
\max _{x_{1 i}, x_{2 i}} E\left\{\max _{b, \varepsilon_{i}} p\left(\left[\eta x_{1 i}{ }^{\psi}+(1-\eta) x_{2 i}{ }^{\psi}\right]^{\frac{1}{\psi}} \varepsilon_{i}\right)-w\left(\eta x_{1}+(1-\eta) x_{2}\right) \varepsilon_{i}-(R-1) b\right\}
$$

subject to the firm's CIA constraint,

$$
B \geq \eta w x_{1 i} \varepsilon_{i}
$$

We need to normalize the firm's choice variables and we choose the normalization

$$
\eta x_{1 i}+(1-\eta) x_{2 i}=1
$$

hence, $\eta x_{1 i}$ is the fraction of total inputs that must be paid for with cash in industry $i$.

\section{B. The Household's Problem}

Before the realization of $T_{t}$, the household must divide its initial money holdings $\Omega_{t}$ between $m_{t}$ and $n_{t}$. Later, in the asset market, the household chooses how much to lend or borrow, as well as how many state-contingent securities to buy. The household also chooses how many hours to work and the price of its intermediate goods. ${ }^{5}$ Finally, in the goods market, the household chooses how much cash to spend on cash goods and how many credit goods to acquire.

Here, too, we will simplify the exposition of the household's problem by implicitly imposing that the consumption levels of all cash goods are the same, as are the consumption

\footnotetext{
${ }^{4}$ We found that without this feature, output could decline after a positive money shock in the liquidity model. We experimented with different approaches that would guarantee a liquidity effect in this model, including specifying the fraction of the value of inputs that must be paid with cash. These alternative specifications generated very similar results and are discussed in some detail in Cole and Ohanian (1997). The approach we take in this paper preserves symmetry between households and firms in that it allows the interest elasticity of firm money demand to depend on the production function parameters, just as the household interest elasticity depends on the utility function parameters.

${ }^{5}$ Recall that with free entry, the prices of all intermediate goods will be the same.
} 
levels of all credit goods. This constraint is without loss of generality, given the concavity of the utility function. The CES consumption aggregate is therefore given by

$$
c=\left[\gamma\left(c_{1}\right)^{\theta}+(1-\gamma)\left(c_{2}\right)^{\theta}\right]^{1 / \theta}
$$

where $c_{1}$ is the consumption of level of cash goods and $c_{2}$ is the consumption level of credit goods.

We also find it convenient to express the household's problem in a recursive fashion. The value function of the household, given its initial money holdings and the total level of the money stock, $V(\Omega, M)$, is implicitly defined by

$$
V(\Omega, M)=\max _{m, n} E_{g}\left\{\max _{c, l} u(c, l)+\beta E V\left(\Omega^{\prime}, g M\right)\right\}
$$

subject to constraints (1)-(4).

Since households are indifferent as to which intermediate goods they supply, we can express the market-clearing condition for intermediate inputs as a single aggregate marketclearing condition

$$
\begin{aligned}
l & =\gamma\left(\eta x_{11}+(1-\eta) x_{21}\right) \varepsilon_{1}+(1-\gamma)\left(\eta x_{12}+(1-\eta) x_{22}\right) \varepsilon_{2} \\
& =\gamma \varepsilon_{1}+(1-\gamma) \varepsilon_{2}
\end{aligned}
$$

where the last equality follows from our normalization (6). The other market-clearing conditions are

(8) $c_{1}=\left[\eta x_{11} \psi+(1-\eta) x_{21}\right]^{\frac{1}{\psi}} \varepsilon_{1}$

(9) $\quad c_{2}=\left[\eta x_{12}{ }^{\psi}+(1-\eta) x_{22}{ }^{\psi}\right]^{\frac{1}{\psi}} \varepsilon_{2}$

(10) $b=n+T$

(11) $m+n=M$. 


\section{The Sticky Price Model}

We construct our sticky price model along the lines of Blanchard and Kiyotaki (1987). Other contributions in the sticky price literature include Taylor (1979), Rotemberg (1984), Mankiw (1985), Svensson (1986), Ball and Romer (1989), and Chari, Kehoe, and McGrattan (1996). To develop the sticky price model, we simply make two modifications to our basic environment: we assume that firms are monopolistically competitive and that they must set their nominal price one period in advance. We choose one-period price setting since it provides the simplest environment to study the question of interest. As is standard in sticky price models, we assume that output of final goods is demand determined: we assume that households can purchase as much of the output as they want at the predetermined price.

The state in period $t$ is given by $s_{t}=\left(M_{t}, g_{t}, p_{t}^{1}, p_{t}^{2}\right)$, where $M_{t}$ is the beginning-ofperiod money stock, $g_{t}$ is the gross growth rate of money, and the initial predetermined cash and credit prices are given by $p_{t}^{1}:[0, \gamma] \rightarrow \Re_{+}$and $p_{t}^{2}:(\gamma, 1] \rightarrow \Re_{+}$.

\section{A. The Consumer's Problem}

The state is completely realized at the start of the period; hence, the value function of the household, given its initial money holdings, the total level of the money stock, and the state, is given by $V(\Omega, M, s)$ and is implicitly defined by

$$
V(\Omega, M, s)=\max _{c, x} u\left(\left[\int c_{t}(i)^{\theta} d i\right]^{1 / \theta}, l\right)+\beta E_{s^{\prime}} V\left(\Omega^{\prime}, g M, s^{\prime}\right)
$$

subject to (1)-(4). We can reduce these restrictions to

$$
\begin{aligned}
\Omega^{\prime}\left(s^{\prime}\right)= & \Pi+w l-\int_{\gamma}^{1} p(i) c(i) d i+R(\Omega+T- \\
& \left.\int_{0}^{\gamma} p(i) c(i) d i-\sum_{\tilde{s}} Q(\tilde{s}) q_{t}(\tilde{s})\right)+q\left(s^{\prime}\right)
\end{aligned}
$$

where we assume that the CIA constraints (2) and (4) hold as equalities. ${ }^{6}$

\footnotetext{
${ }^{6}$ We have made use of the fact that here, too, production arbitrage implies that all intermediate goods prices must be the same.
} 


\section{B. The Producer's Problem}

The problem of individual cash final goods producers who must set their price in advance is

$$
\max _{p(i)} E\left\{\max _{x_{1}, x_{2}}\left[p(i) c\left(i ; p(i), \bar{p}\left(s^{\prime}\right), c\left(s^{\prime}\right)\right)-w\left(s^{\prime}\right)\left(R\left(s^{\prime}\right) x_{1}\left(i, s^{\prime}\right)+x_{2}\left(i, s^{\prime}\right)\right)\right] R\left(s^{\prime}\right)^{-1} Q\left(s^{\prime}\right)\right\}
$$

subject to the production constraint:

$$
\left[\eta x_{1}(i ; s)^{\psi}+(1-\eta) x_{2}(i ; s)^{\psi}\right]^{\frac{1}{\psi}}=c\left(i ; p(i), \bar{p}\left(s^{\prime}\right), c\left(s^{\prime}\right)\right)
$$

where we impose the firm's CIA constraint (5) as an equality. ${ }^{7}$

Substituting the household's demand function yields into the firm's first-order conditions and simplifying, we have

$$
E\left\{\left[\theta p(i)-\lambda\left(s^{\prime}\right)\right]\left(\frac{R\left(s^{\prime}\right)}{\bar{p}\left(s^{\prime}\right)}\right)^{\frac{1}{\theta-1}} c\left(s^{\prime}\right) R\left(s^{\prime}\right)^{-1} Q\left(s^{\prime}\right)\right\}=0 .
$$

For a credit good producer, this condition is

$$
E\left\{\left[\theta p(i)-\lambda\left(s^{\prime}\right)\right]\left(\frac{1}{\bar{p}\left(s^{\prime}\right)}\right)^{\frac{1}{\theta-1}} c\left(s^{\prime}\right) R\left(s^{\prime}\right)^{-1} Q\left(s^{\prime}\right)\right\}=0 .
$$

In expectation terms, these are the same conditions that one would derive for a price-setter within the period, since these conditions imply that $p(i)=\lambda / \theta$, which is the standard constant markup over marginal cost formula, where $\lambda$ is the Lagrangian multiplier on the production constraint. These pricing equations imply that all cash producers will set the same price and all credit producers will set the same price. We denote these prices by $p_{1}$ and $p_{2}$, respectively.

Since all the cash producers will choose price $p_{1}$ and the credit producers will choose price $p_{2}$, this implies from the symmetry of preferences that the quantity demanded by households of each of the cash goods will here, too, be the same, as will the quantity demanded of each of the credit goods. Therefore, we will again denote these quantities by $c_{1}$ and $c_{2}$, respectively. The market-clearing conditions for final goods (8 and 9), bonds (10), and money (11) will be the same.

\footnotetext{
${ }^{7}$ Note that in this model, we did not alter the firm's problem in hiring inputs as we did in the liquidity model.
} 
To preserve the liquidity effect in the limited participation model, recall that it was necessary to make the firms first choose their input ratios and later their scale of operation. Since that is not necessary in the sticky price model, we have not changed the firm's maximization problem presented in Section 2 to include a separate scale variable. Hence, the aggregate market-clearing condition for intermediate goods is given by

$$
l=\gamma\left(\eta x_{11}+(1-\eta) x_{21}\right)+(1-\gamma)\left(\eta x_{12}+(1-\eta) x_{22}\right),
$$

and $x_{i j}$ is interpreted here as the level of input $i$ in industry $j$. As will become clear in the next section, the substantive conclusion of the analysis would not be changed by making the firms choose their input ratios at the same time as they choose their prices.

In this model, we assume that the price-setting technology is fixed: all nominal prices must be set one period in advance. Theoretically, it is well-known that changes in price-setting will change the nonneutrality of money in a sticky price model. Quantitatively, it is very hard to know if price stickiness has changed much over the postwar period, since few explicit data are available. Cecchetti (1986) reports that the frequency of price changes increased for newsstand magazines in the late 1970s, and Kashyap (1995) reports a similar finding for L.L. Bean catalog prices. There is less direct evidence available for broader measures of goods prices. An alternative approach to analyzing broader price measures has been to infer changes using a measure of price dispersion, as in Cecchetti (1985). While he infers changes in the frequency of price-setting in the early 1960s, there do not appear to be other significant changes over time. (See Cecchetti (1985), p. 947.)

\section{A Basic Analysis With Linearized Models}

To gain a basic understanding of how money affects output in each model, we linearize each model around its steady state.

\section{A. Linearizing the Liquidity Model}

In the liquidity model, we take as given all variables determined before the realization of the money shock. Those variables include the firms' input mix $\left(x_{i j}\right)$ and the composition of money holdings ( $m$ and $n$ ). To understand the relationship between money shocks and output,

\footnotetext{
${ }^{8}$ We thank John Taylor for helpful discussions on this issue.
} 
we focus on three equations. Two of these equations are household first-order conditions. The first equation is the static first-order condition that governs the optimal choices of credit consumption and leisure:

$$
u_{l}+\left[u_{c}\left(\frac{c}{c_{2}}\right)^{1-\theta} \frac{1}{p_{2}}\right] w=0
$$

The second equation is the standard intertemporal first-order condition for the credit good:

$$
\frac{u_{c}\left(\frac{c}{c_{2}}\right)^{1-\theta}}{p_{2}}=\frac{1}{g} \beta E\left\{R \frac{u_{c}\left(\frac{c}{c_{2}}\right)^{1-\theta}}{p_{2}}\right\} .
$$

When we assume that utility is given by

(15) $\frac{c_{t}^{1-\sigma}-1}{(1-\sigma)}-l_{t}$

linearizing yields the following expressions:

$$
\begin{aligned}
& \text { (16) }-\sigma \frac{d c}{c}+(1-\theta)\left(\frac{d c}{c}-\frac{d c_{2}}{c_{2}}\right)-\frac{d p_{2}}{p_{2}}+\frac{d w}{w}=0 \\
& \text { (17) }-\sigma \frac{d c}{c}+(1-\theta)\left(\frac{d c}{c}-\frac{d c_{2}}{c_{2}}\right)-\frac{d p_{2}}{p_{2}}+\frac{d g}{g}=0 .
\end{aligned}
$$

The third equation is the CIA constraint for the firm, which can be used to solve for the nominal wage, $w$ :

$$
w=\frac{n+g-1}{\eta\left(\gamma x_{11} \varepsilon_{1}(1-\gamma) x_{12} \varepsilon_{2}\right)} .
$$

Linearizing this third equation, and making use of the fact that equations (16) and (17) imply that $d w / w=d g / g$, yields a linearized expression involving just two objects: the $\varepsilon_{i}$, which determine the overall level of output, and changes in the growth rate of money. After some algebra, we obtain the following simple expression that describes how money affects output in this model:

$$
\frac{d \ln (y)}{d \ln (g)}=\left(\frac{m}{n^{*}}\right), n^{*}=n+T
$$

This expression shows that there is an important connection between relative money demands and the nonneutrality of money - the percentage impact of a money shock is determined entirely by the ratio of money held by households to money held by firms. This 
indicates that changes in the composition of money holdings have significant implications for this model. Note that this linear relationship between the composition of money holdings and the nonneutrality of money is independent of the factors that determine relative money holdings. Thus, a 100 percent increase in $m / n^{*}$, whether it is due to changes in the technology parameters governing household and firm money demand, $\{\gamma, \theta, \eta, \psi\}$, or to changes in the average growth rate of money, $g$, implies a 100 percent increase in the real effect of a money shock.

Since there is a connection between unexpected money, output, and the nominal interest rate in this model, we find it useful to derive a linearized expression for the interest rate. This also allows us to implicitly study simple versions of interest rate policy rules. In this model, the interest rate is the price which clears the market for loans after the monetary shock. Since firms are the borrowers in this economy, it is necessary to consider the firm's profit maximization problem to obtain an equation for the interest rate. In order for the scale of operation to be positive and finite, the following zero-profit condition must hold for the firm:

$$
p_{i} X_{i}=w\left(R \eta x_{1 i}+(1-\eta) x_{2 i}\right)
$$

where

$$
X_{i}=\left(\eta x_{1 i}^{\psi}+(1-\eta) x_{2 i}^{\psi}\right)^{\frac{1}{\psi}}
$$

gives the output per unit of input. Making use of the fact that $c_{i}=X_{i} \varepsilon_{i}$ and using the household's CIA constraint, we obtain the following equation for the interest rate:

$$
R=\frac{\frac{m}{\gamma \varepsilon_{1}}-w(1-\eta) x_{21}}{w \eta x_{11}} .
$$

Totally differentiating, we obtain

$$
d R=-\frac{1}{\eta}\left(\frac{m}{n^{*}}\right)\left(d \ln \left(\varepsilon_{1}\right)+d \ln (g)\right)\left(\frac{\gamma x_{11} \varepsilon_{1}+(1-\gamma) x_{12} \varepsilon_{2}}{\gamma x_{11} \varepsilon_{1}}\right) .
$$

Since $d \ln \left(\varepsilon_{1}\right) / d \ln (g)>0$, the interest rate clearly falls in response to a positive money shock, and the size of the decline depends on the ratio of household money to firm money, $m / n^{*}$. As 
$\gamma \rightarrow 1, d \ln \left(\varepsilon_{1}\right)=d \ln (y)$, and, making use of (18), we obtain a particularly simple expression for how the interest rate responds to a money shock:

(19) $\frac{d R}{d \ln (g)}=-\frac{1}{\eta}\left(\frac{m}{n^{*}}\right)\left(1+\frac{m}{n^{*}}\right)$.

In this case, the change in the interest rate is a quadratic function of the ratio of household to firm money holdings, as opposed to the linear relationship between output and money presented above. Moreover, for the case of $\gamma$ near 1, we can use implicit differentiation to understand the connection between interest rates and output and thus analyze a simple interest rate rule that sets the interest rate indirectly by setting the growth rate of money. Using (18) and (19), we obtain

$$
\left.\frac{d \ln (Y)}{d R}\right|_{\gamma \approx 1}=-\eta \frac{1}{1+\frac{m}{n^{*}}} .
$$

For this special case, the change in output associated with a change in the interest rate depends on the composition of money holdings, $\frac{m}{n^{*}}$, and the fraction of inputs purchased by firms that are subject to the CIA constraint, $\eta$. In sum, the relationships between output and interest rates, output and money, and interest rates and money all depend in important ways on the composition of money holdings.

What is the economic mechanism that connects changes in the composition of money holdings to the nonneutrality of money? If a 1 percent increase in the total money stock must be absorbed by agents who hold only one-tenth of the total money stock, then their money holdings must rise by 10 percent, and at the margin, equilibrium prices of goods and assets must change to induce them to hold 10 percent more money. Alternatively, if those who participate in the transfer alternatively hold half the money stock, then their money holdings need to rise by just 2 percent, and equilibrium prices do not have to change as much. Given this intuition, consider a reduction in the fraction of the money stock that the household deposits in the asset market, which implies that $m / n^{*}$ rises. Now firms hold a smaller fraction of the money stock. Thus, an unanticipated change in the total money stock of a given size leads to a larger percentage increase in loanable funds, and the interest rate must drop more to induce firms to absorb these additional funds. 
These theoretical results highlight the importance of relative money demands in this model. This leads us to examine changes in the postwar composition of money holdings between firms and households. We present data on compositional shifts in money holdings in Section 6.

\section{B. Linearizing the Sticky Price Model}

We next analyze the sticky price model. Since both models share the same basic environment, the first-order condition governing optimal choices of leisure and credit consumption and the intertemporal first-order condition are unchanged. Consequently, we also obtain (16) and (17) in this linearized model. The only difference is that $d p_{2} / p_{2}=0$ in these equations, since this price is set in advance:

(20) $-\sigma \frac{d c}{c}+(1-\theta)\left(\frac{d c}{c}-\frac{d c_{2}}{c_{2}}\right)+\frac{d w}{w}=0$
$(21)-\sigma \frac{d c}{c}+(1-\theta)\left(\frac{d c}{c}-\frac{d c_{2}}{c_{2}}\right)+\frac{d g}{g}=0$.

While these linearized equations are the same as those in the liquidity model, the appropriate wage equation is much different, since in the sticky price model, household and firm money holdings ( $m$ and $n$ ) are determined after the money shock is realized. Aggregating the household and firm CIA constraints and making use of the fact that $m+n=\Omega$, which we normalize to one, yield

$$
w=\frac{g-p_{1} \gamma c_{1}}{\eta\left(\gamma x_{11}+(1-\gamma) x_{12}\right)} .
$$

Given that three endogenous variables appear on the right-hand side of this wage expression $\left(c_{1}, x_{11}, x_{12}\right)$, linearizing this equation and using equations (20) and (21) does not generally provide a simple characterization of how money affects output. Instead, the nonneutrality of money depends in a complex way on a number of parameters and, in particular, on two of the technology parameters that affect money demand of households and firms ( $\gamma$ and $\eta$ ). This suggests that the nonneutrality of money in the sticky price model will be sensitive to changes in money demands.

In one case, however, we obtain a very simple and surprising characterization of how money affects output. This is the case in which $\theta$ is near one. We can show that as $\theta \rightarrow 1$, 
the term $\left(\frac{d c}{c}-\frac{d c_{2}}{c_{2}}\right) \rightarrow 0$, which clearly implies that $(1-\theta)\left(\frac{d c}{c}-\frac{d c_{2}}{c_{2}}\right) \rightarrow 0$ as $\theta \rightarrow 1$. In this case, equation (21) implies that

$$
\frac{d \ln (y)}{d \ln (g)}=\frac{1}{\sigma} .
$$

For the case in which $\theta$ is near one, the real effect of a money shock in the linearized model is determined solely by a real factor, the household's intertemporal elasticity of substitution. This implies that the nonneutrality of money is insensitive to changes in velocity, the composition of money holdings, or other monetary phenomena. The reason changes in money demand do not affect the nonneutrality of money is that households can very easily substitute between cash goods and credit goods. For this special case, money's medium of exchange role is irrelevant to understanding the nonneutrality of money. Instead, money is nonneutral because it is the unit of account: prices are denominated in currency units and are set in advance. Note these results depend only on the preference side of the model. Hence, they would not be substantively affected if we made the firms choose their input ratios in advance, as in the liquidity model.

Based on these results, it is important to know the range of $\theta$ for which this invariance roughly holds and, for quantitative work, whether calibrated or estimated values of $\theta$ are in this range. This range may be large, since both terms in the expression $(1-\theta)\left(\frac{d c}{c}-\frac{d c_{2}}{c_{2}}\right)$ go to zero as $\theta \rightarrow 1$. We study these issues in Section 7 .

To summarize these theoretical results, we find that for preferences of the form (15), the liquidity model predicts that the effect of a money shock is linearly related to the composition of money holdings. For the sticky price model, however, the effect of a money shock depends critically on the substitution elasticity between cash and credit goods. If the elasticity is sufficiently high, then the nonneutrality of money is invariant to changes in money demand or to other monetary phenomena. If the elasticity is low, however, then changes in money demand will generally affect the nonneutrality of money in this model.

\section{Velocity and the Composition of Money Holdings: 1950-1997}

There have been sharp changes in the stock of money held by households and firms relative to output over the postwar period, as well as changes in velocity, which is defined as the aggregate stock of money relative to output. These changes have prompted much of 
the concern over postwar money demand. We present these postwar data in this section and begin by presenting data on velocity. Velocity for different transactions measures of money over the period from 1950 to 1995 is presented in Figures 1 and 2. Figure 1 shows that the ratio of nominal gross domestic product to M1 (M1 velocity) has risen by a factor of about three between 1950 and 1980. Since then, there have been no significant trends in M1 velocity. ${ }^{9}$ However, it is important to note that the rise in M1 velocity may be understated, since it has been estimated that the use of U.S. currency outside the country has increased considerably. Recent estimates are that in 1995, more than half of the currency outstanding was held overseas and that during the 1990s, the stock of currency outside the United States grew at approximately three times the rate of the domestic stock. (See Porter and Judson (1996).)

The velocity of other transactions measures of money has also grown significantly in the postwar period. A widely used alternative to simple-sum monetary aggregates, such as M1, is Divisia monetary aggregates. (See, for example, Barnett, Offenbacher, and Spindt (1984).) This approach breaks the perfect substitutability assumption implicit in simple-sum aggregates and instead weights components on the basis of the flow of monetary services. Velocity measures constructed with Divisia indexes for M1, M2, and M3 are presented in Figure 2. These measures also increase sharply over time, and in contrast to M1 velocity, Divisia M2 and M3 velocities continue to rise after 1980.

The results from our analysis of linearized models indicate that variations in the composition of money holdings between households and firms would have important implications for the liquidity model. Figure 3 presents the ratio of money held by households to money held by all businesses in the United States over the postwar period. All data are drawn from the Federal Reserve Board's Flow of Funds data and include cash plus checkable deposits. ${ }^{10}$ These data show that household money holdings relative to business money holdings increased between 1952 and 1980, rising from about 1.4 to about 2.9. Since 1980, however, this ratio

\footnotetext{
${ }^{9}$ The money supply data before 1959 were constructed by adding unrevised currency and demand deposit data. Until the mid-1970s, M1 was composed almost entirely of currency and demand deposits. The unrevised currency and demand deposit data differ from the revised figures available after 1959 primarily in that their seasonal factors have not been adjusted.

${ }^{10}$ Checkable deposits include demand deposits, travelers checks, NOW accounts, and automatic transfer service accounts.
} 
has declined sharply, falling from 2.9 to less than 1.

These compositional changes are robust to alternative definitions of money holdings. For example, we also observe large changes if total business money holdings are replaced with corporate money holdings (Figure 4), or if money market mutual funds, which are claims issued by mutual funds against short-term liquid assets, are added to money holdings of both firms and households (Figure 5).

Given these data, our analysis of the linearized liquidity model indicates that the real effect of a money shock in the liquidity model would have increased by 100 percent between 1952 and 1980, and would have fallen about 65 percent between 1980 and today. Thus, this model predicts instability in the nonneutrality of money over the postwar period and implies considerable changes in the relationship between money and output, money and interest rates, and interest rates and output.

We use the flow of funds measure of household and firm money holdings because it is the only compositional data available over the entire postwar period. Note that the flow of funds data measure household money holdings as the residual of money holdings for which ownership cannot be ascertained. Since household money is likely to be measured with error, it is natural to ask if this has implications for our finding of instability in the liquidity model. Measurement error has implications for the prediction of instability only if this error is systematically responsible for the large observed changes in this ratio, and that the true ratio has instead been constant over time.

The observed compositional changes are unlikely to be due to measurement error for three reasons. First, there is an independent measure of the composition of money holdings that also shows large changes in this ratio. The Federal Reserve's Demand Deposit Ownership Survey separately tabulates the ownership of demand deposits of financial firms, nonfinancial firms, households, and foreigners. These survey data, which are available only between 1970 and the second quarter of 1990, show a 38 percent decline in the ratio of household demand deposits to firm demand deposits between the peak in 1979:1 and the trough in 1989:4. This decline exceeds the 33 percent decline in holdings of deposits and currency observed in the flow of funds measure over the same period.

Second, Porter and Judson (1996) suggest that recent compositional changes may be 
understated, rather than overstated, due to measurement error. In particular, their estimate that the fraction of money held outside the United States has been growing significantly in recent years implies that the true decrease in the ratio of household to firm money that has occurred since the late 1970s may actually be greater than the large observed decline.

Third, the sharpest changes in this ratio occurred during periods in which there have been important financial developments that would be expected to change the composition of money holdings as observed in the data. In particular, about half of the 1952-1980 increase in the ratio of household to firm money holdings occurred during the 1970s, which is the period in which there was a sharp increase in the array of financial services offered to firms. (See Beehler (1978) and Dotsey (1984).) This development, which allowed firms to economize on money holdings, would be expected to lead to an increase in the ratio of household money to firm money. Similarly, the sharp decrease in the ratio of household money to firm money that has occurred since the late 1970s has taken place during a period of rapid growth in the use of personal credit cards and in the use of automatic teller machines (ATMs). These developments have allowed households to economize on money holdings and would be expected to lead to a decline in the ratio of household money to firm money.

It therefore seems reasonable to conclude that these postwar compositional changes in money holdings are not simply an artifact of measurement error. ${ }^{11}$

\section{Monetary Trends and the Nonneutrality of Money: 1952-1997}

In this section, we examine the implications of changes in velocity and the composition of money holdings for the nonneutrality of money in versions of our models which do not assume that preferences are separable between consumption and leisure and are linear in

\footnotetext{
${ }^{11}$ In this analysis, we follow the money demand and monetary business cycle literature in interpreting holdings of M1 as money held primarily for transaction purposes. This conventional interpretation seems reasonable, given the observation that large swings in the composition of money holdings between firms and households occurred during periods of significant changes in transaction technologies for both firms (1970s) and households (1980s). Nonstandard interpretations of M1 holdings on the part of households or firms, such as money that is held primarily as a buffer stock, or money that has piled up due to a delay in its ultimate disbursement, also raise stability questions for the limited participation model. To see this, recall that the agents who participate in the asset market at the time of the monetary transfer need to have a demand for cash at the margin. Otherwise, the real effect of a money shock would have little or no effect. This suggests that changes in the size of the buffer stock of money over time, for example, could be an additional source of instability in the nonneutrality of money in this model.
} 
leisure or that there is perfect substitutability between cash and credit goods and inputs. In particular, we choose values for these substitution elasticities so that the models generate empirically plausible interest elasticities of money demand.

To accomplish this, we analyze the stochastic steady state of each model for three different calibrations, each of which corresponds to three different points in the postwar period. The three points in time are 1952, when both velocity and $M_{h} / M_{f}$ are low, 1980, when velocity and $M_{h} / M_{f}$ are high, and 1997, when velocity remains high, but $M_{h} / M_{f}$ is at its postwar low. We numerically solve the models for these three calibrations and compute the elasticity of output with respect to a money shock. For each date, we calibrated the model to match velocity, the composition of money holdings between firms and households, and the interest rate. We also calibrated each model to a desired interest elasticity of money demand. We present the observations that we use to calibrate the models in Table 1, and we discuss the exact calibration below. ${ }^{12}$

Table 1

Data for Calibration

\begin{tabular}{|c|c|c|c|}
\hline Year & Interest Rate & Velocity & Household/Firm Holdings \\
\hline \hline 1952 & $1.8 \%$ & 2.9 & 1.4 \\
\hline 1980 & $11.5 \%$ & 7.1 & 2.75 \\
\hline 1997 & $5.1 \%$ & 7.5 & 1.0 \\
\hline
\end{tabular}

We use the following utility function, which is widely used in the equilibrium business cycle literature:

$$
u(c, l)=\frac{\left[c^{\zeta}(1-l)^{1-\zeta}\right]^{1-\sigma}-1}{1-\sigma} .
$$

\footnotetext{
${ }^{12}$ In our analysis of stochastic steady states, note that households and firms are unaware of any future changes in government policy and the parameters governing money demand. Incorporating anticipations of these changes into the model would complicate the analysis considerably and in our view, not change the findings in any important ways. This is because the differences in policy and parameters that we consider change the steady states of both models trivially. For each model, the steady state levels of total labor input and total output across the three dates we study are all within 0.5 percent of each other. This suggests that even in a model with stronger intertemporal links, such as the inclusion of capital accumulation, transition dynamics arising from the anticipation of these changes would be quantitatively unimportant. We thus feel it is reasonable to pursue this much simpler analysis.
} 
For the simulation we present, we choose values of $\sigma=2$ and $\zeta=0.5$. Since we will be calibrating the money supply process at the three dates so that the model nominal interest rate matches the observed interest rate at each date, it is useful to choose a value of $\beta$ that produces a low real interest rate. Therefore, we set $\beta=0.9975$, and we interpret the model as a quarterly model. These parameter values are common across the three calibrations.

The only source of uncertainty in the model is the growth rate of the money supply. To keep the analysis simple, we specify a two-state money growth process $\left\{g_{i}^{H}, g_{i}^{L}\right\}$ (high growth and low growth), $i=\{1952,1980,1997\}$, that is i.i.d. The i.i.d. specification allows us to abstract from output variability caused by changes in anticipated inflation. In standard CIA models, such as Cooley and Hansen (1989), expected inflation alters labor supply decisions, since wages earned in period $t$ cannot be spent until period $t+1$. With i.i.d. shocks, however, anticipated inflation is constant, and all output variability is necessarily due to the unexpected change in the money supply.

The remaining parameters to be calibrated are the money supply process at different dates $\left\{g_{i}^{H}, g_{i}^{L}\right\}$, the values for the share parameters $\gamma_{i}$ and $\eta_{i}$, and the values for the curvature parameters $\theta_{i}$ and $\psi_{i}$.

We choose the money growth rates for 1952, $\left\{g_{1952}^{H}, g_{1952}^{L}\right\}$, such that the average nominal interest rate in the model is equal to the actual value in the data (1.8 percent for a three-month T-bill). We set the innovation variance of money growth to be 0.5 percent. For computational convenience, we keep the innovation variance low to avoid a corner when nominal interest rates are zero. We follow the same procedure for calibrating money growth in 1980 and 1997, keeping the percentage innovation variance in money growth fixed at 0.5 percent. For these years, the average interest rate for three-month T-bills was 11.5 percent (1980) and 5.1 percent (1997). (See Table 1.)

To calibrate the other parameters, we assume that the parameters governing the elasticity of substitution between goods for households $\left(\theta_{i}\right)$ and for firms $\left(\psi_{i}\right)$ are constant across the three dates and are also the same. Thus, $\theta_{i}=\theta, \psi=\theta$. This requires we choose a single value for $\theta$ that is common across the three dates and separate values for the share parameters $\gamma_{i}$ and $\eta_{i}$ at the three dates. We choose $\theta$ and the share parameters in 1952 to hit three targets: (1) velocity in the model is equal to M1 velocity in 1952 (2.9), (2) the ratio of 
money held by households to that held by firms in the model is equal to that in 1952 (1.4), and (3) the household interest semi-elasticity of money demand is -0.04 , which has been estimated by Mankiw and Summers (1986). Keeping the curvature parameters $\theta$ and $\psi$ fixed, we choose the share parameters for 1980 and 1997 such that velocity and the composition of money holdings in the model are equal to those at these two dates. ${ }^{13}$ Thus, changes in the money demands of firms and households in our model are accommodated through changing transactions technologies by changing the share of goods that can be purchased with credit. ${ }^{14}$

We present the parameter values and the results of this analysis in Table 2 . In columns four and eight, we present the normalized percent standard deviations of output for the liquidity and sticky price models, where the normalization is with respect to the 1952 value. The results for the liquidity model are very similar to the theoretical predictions from the linearized analysis of the model with separable preferences and linearity in leisure - the nonneutrality of money moves in lockstep with the observed changes in the ratio of household to firm money. Consequently, this model predicts that the real effect of a money shock is much smaller today than in the 1970 s and early 1980 s and, in fact, is smaller today than at any other time in the postwar period.

Table 2

Results for Interest Semi-Elasticity of $-\mathbf{0 . 0 4}(\theta=\psi=0.977)$

Liquidity Model
\begin{tabular}{|c|c|l|l||r|l|l|}
\hline \hline Year & $\gamma$ & $\eta$ & $\% \operatorname{std}(y)$ & $\gamma$ & $\eta$ & $\% \operatorname{std}(y)$ \\
\hline 1952 & .83 & .63 & 1.00 & .83 & .63 & 1.00 \\
\hline 1980 & .70 & .37 & 1.95 & .70 & .38 & 1.03 \\
\hline 1997 & .39 & .38 & 0.70 & .39 & .39 & 1.03 \\
\hline
\end{tabular}

\footnotetext{
${ }^{13}$ We use a nonlinear equation solver to compute the equilibrium at each date. The maximum deviation of any equation is no greater than e-04 percent.

${ }^{14}$ We have also studied how the nonneutrality of money changes in response to changes in money demand in a Baumol/Tobin-type environment. We conducted this analysis by varying the number of trips firms and households made to the bank each period and assessing how the effect of a money shock changes. Our main findings were very similar to those reported here: the real effect of a money shock in the liquidity model was linear in the ratio of household to firm cash, and the real effect of a money shock in the sticky price model was basically unchanged.
} 
As in the linearized analysis, these results also show that the liquidity model predicts that the relationships between money shocks and interest rates, and interest rates and output, have changed over time. The liquidity effect of a money shock on interest rates increases considerably between 1952 and 1980 and then falls after 1980. An annualized 1 percent unexpected increase in the money supply drives down the annualized interest rate about 27 basis points in 1952, 184 basis points in 1980, and 50 basis point in 1997. The effect of a change in the interest rate on output of a given percent size, $\frac{d \ln (Y)}{d \ln (R)}$, rises by about 250 percent from -3.6 to -12.9 between 1952 and 1980 and then declines nearly 50 percent to -7.6 between 1980 and $1997 .^{15}$

In sharp contrast to the liquidity model, there is virtually no change in the nonneutrality of money in the sticky price model across the three stochastic steady states, despite large changes in the share parameters and interest rates. This suggests that a calibration of $\theta$ to produce an interest semi-elasticity of -0.04 , which tends to be at the low end of estimates, is in the range for which the invariance result roughly holds. In general, we find that to produce a reasonable interest elasticity of money demand requires a high elasticity of substitution between cash and credit goods. Thus, to produce a higher interest semi-elasticity of money demand, such as that estimated by Lucas (1988) or Stock and Watson (1993), we would need an even higher value of $\theta$, and this value clearly would be in the invariant region. Since there is little change in the relationship between money shocks and interest rates or between interest rates and output in this model, we do not discuss these results.

It is also interesting to note the implications of the postwar changes in velocity and the composition of money holdings for the calibrated share parameters $\gamma$ and $\eta$. To capture the postwar trends in velocity and the composition of money holdings, the share parameters $\gamma$ and $\eta$ fall significantly over the postwar period. For the household, most of the change occurs after 1980, which is the period in which such financial innovations as ATMs and credit cards

\footnotetext{
${ }^{15}$ In these experiments, we kept the curvature parameters fixed and varied the share parmaters. If we varied both the curvature parameters and the share parameters, it is possible to change the curvature parameters in such a way as to maintain a stable relationship between interest rates and output in the liquidity model over the postwar period. However, this requires a substantial reduction in the curvature parameters, which implies a considerable decrease in the elasticity of substitution between goods for households, and inputs for firms, over the postwar period. Moreover, while reducing substitution elasticities this way can preserve a stable relationship between interest rates and output, it doesn't preserve a stable relationship between money and interest rates or between money and output.
} 
came into widespread use. For the firm, virtually all the change occurs before 1980, which is the period in which there were important changes in firm cash management. Note that these patterns depend somewhat on the choice of the curvature parameters. For example, since interest rates rise from 1952 to 1980 and fall, on average, from 1980 to 1997, choosing a lower value for the parameter $\psi$ implies that the decline in $\eta$ continues over the entire period. Since these changes did not affect our results for the nonneutrality of money and since measuring technological progress in financial intermediation is not the focus of this study, we do not pursue this issue further.

To assess the robustness of these results, we conducted a number of other experiments in which we changed the parameters $\{\beta, \zeta, \sigma, \gamma, \theta, \eta, \psi\}$. Since the results are similar to those already shown, we present these experiments in the Appendix and only summarize the results here. For both models, changes in the values of the preference parameters $\beta, \zeta$, and $\sigma$ do not affect the results.

For the liquidity model, we verified that the composition of money holdings is the only factor important for changing the real effect of a money shock and that the relationship between money holdings and a money shock is linear. Moreover, the source of the compositional change, whether changes in the share parameters $\gamma$ and $\eta$, the curvature parameters $\theta$ and $\psi$, or variations in the inflation rate, is unimportant - any factor that changes this ratio, whether it is different movements along the money demand curves for firms and households, or shifts in the money demand curves for firms and households, changes the real effect of a money shock in exactly the same linear manner.

For the sticky price model, an interesting issue is the range for $\theta$ (which governs the substitution elasticity between goods for households) for which the real effect of a money shock is roughly invariant to changes in the demand for money. We found that this range is not fixed, but depends somewhat on the share parameter $\gamma$. This is because both these parameters govern the interest semi-elasticity of money demand. Given this connection, we did find a fixed range of the interest semi-elasticity for which the real effect of a money shock is invariant. We therefore found it more convenient to report a fixed range in terms of the interest semi-elasticity than a variable range in terms of $\theta$. Accordingly, we found that the real effect of a money shock in this model is not very sensitive to any changes in money demands 
as long as the interest semi-elasticity of money is above -0.01. For an interest semi-elasticity below -0.01 , lowering the share parameter $\gamma$ or $\eta$ leads to an increase in the real effect of a money shock. The lower is the interest elasticity of money demand, the larger is the increase in the real effect. ${ }^{16}$

This increase is due to the fact that changing the share of goods subject to the CIA constraint matters only if cash goods and credit goods are less than perfect substitutes. As this elasticity falls, reducing the importance of the CIA friction leads to higher variability, because with predetermined prices, the variability of output subject to the CIA constraint is largely limited by the change in the money supply. While the result that reducing the importance of money in the economy increases the effect of a money shock is theoretically interesting, it doesn't seem to be very relevant empirically. Most estimates of the interest semi-elasticity of money demand are well above -0.01 .

In this investigation, we have analyzed models in which money is nonneutral for one period. We chose this class of models because they are the simplest to study and because there seems to be no universally accepted approach to introducing persistent nonneutralities into either model. One approach to generating persistence in sticky price models is to assume that there are adjustment costs in changing prices. Similarly, adjustment costs in changing portfolios can be used to generate persistence in the liquidity model. While introducing adjustment costs in our two models would lead to longer-lived effects of an initial shock, this modification would not change the fundamental economic mechanisms that lead to nonneutrality.

\section{Implications for Empirical Analyses}

Many papers have empirically studied the real effects of unexpected money shocks, and several of these papers include analyses of the stability of these effects over time. Since many of these analyses have been conducted with statistical models, such as VARs, there consequently has not been much explicit theoretical discussion of the environments in which temporal stability, or instability, of money shocks should be expected. The conclusion that

\footnotetext{
${ }^{16}$ With an interest semi-elasticity of -0.01 , we found that the real effect of a money shock rises in total about 12 percent as a consequence of the postwar changes in velocity and the composition of money demand.
} 
several researchers working in this area have drawn is that there appear to be no important changes in the effects of money shocks over the postwar period. (See Sims and Zha (1995), pp. 21-22; Christiano, Eichenbaum, and Evans (1996), pp. 37-40; Leeper, Sims, and Zha (1996), p. 23; and Sims (1996), p. 7). ${ }^{17}$ For example, in discussing instability, Sims (1996, p. 7) notes, "I do not mean to argue here that there is no room for improving models by allowing for time variation....However, the amount of time variation apparent in the data is weak, not strong."

Our analysis provides a theoretical complement to these empirical studies and a framework for interpreting this conclusion of stability. The view that the effects of money shocks on output and interest rates are roughly stable over time is consistent with the theoretical prediction of the sticky price model (assuming that there have not been large changes in price stickiness over time), in which the nonneutrality of money is tied to money's unit of account role. However, it seems more difficult to reconcile the view of stability with the prediction of the liquidity model, which implies a very specific form of instability: a 100 percent increase in the real effect of a money shock between 1952 and 1980, followed by a 65 percent decline over the last 17 years, as well as sharp changes in the relationships between money and interest rates and between output and interest rates. Although sampling uncertainty can make it difficult to draw very sharp inferences from empirical models, we are unaware of any work that indicates these distinct types of changes over time. ${ }^{18}$ In fact, Leeper, Sims, and Zha (1996) suggest that there is some evidence that the real effect of a money shock has strengthened in the most recent data, rather than weakened considerably as predicted by the liquidity model. (See Leeper, Sims, and Zha 1996, p. 23, fn. 13.) $)^{19}$

\footnotetext{
${ }^{17}$ In the literature, a money shock has been identified as a shock to a money variable, such as nonborrowed reserves, and alternatively as a shock to an interest rate, such as the Federal Funds rate. The conclusion that there is a relatively stable relationship between money, interest rates, and output has been drawn from both types of identification procedures.

${ }^{18}$ We thank Chris Sims for helpful discussions on this point.

${ }^{19}$ Christiano, Eichenbaum, and Evans (1996) analyze sticky price and liquidity models using impulse response functions. They argue that a shortcoming of the sticky price model is that it predicts countercyclical profits, which is inconsistent with the data. The liquidity model predicts procyclical profits.
} 


\section{Summary and Conclusions}

In this paper, we have studied the implications of changes in money demand for the nonneutrality of money in two widely used classes of monetary business cycle models: liquidity models and sticky price models. We find that changes in the composition of money holdings have important effects: the nonneutrality of money increases linearly with an increase in the ratio of money held by households to money held by firms. Given the large postwar compositional changes in money holdings, this model suggests that the potency of monetary policy has been varying over time and that the ratio of household to firm money holdings provides a barometer for gauging the effectiveness of policy. Moreover, the model predicts sharp changes in the relationship between money and output, money and interest rates, and output and interest rates. In this model, if money's medium of exchange role continues to decline, the nonneutrality of money will be unchanged only if the composition of money holdings remains unchanged. This sensitivity is independent of whether these changes were due to different movements along given money demand schedules of firms and households or different shifts in the money demand schedules of firms and households.

In contrast, the nonneutrality of money in the sticky price model is virtually invariant to changes in money demand for parameter values that yield reasonable interest elasticity. This invariance suggests that the potency of monetary policy is not affected by these monetary trends. Moreover, in this model, money can virtually disappear from the economy as a medium of exchange while leaving the nonneutrality of money unaffected.

These differences are due to fundamental differences in the nonneutrality of money in the two models. In the liquidity model, the nonneutrality of money is due to money's medium of exchange role: both households and firms have transactions demand for cash, and household portfolio decisions are made before the money shock. In the sticky price model, money's medium of exchange role does not have important implications for the nonneutrality of money, provided that money demand is plausibly interest elastic. Instead, nonneutralities in this model are due to money's unit of account role: prices are set in advance of the money shock and are denominated in currency units.

Theoretically, we conclude from our findings that it is reasonable to presume stationarity for the sticky price model. As long as there are no changes to money's unit of account role 
and no changes in price stickiness, the nonneutrality of money will be unaffected. However, based on our findings, a presumption of nonstationarity exists for the liquidity model. This conclusion contrasts sharply with the standard view in business cycle analysis that trends are unimportant for theoretical models. In particular, changes in money's medium of exchange role that are due to changes in either government policy or changes in transactions technologies can affect the nonneutrality of money in the liquidity model. Consequently, these findings raise questions regarding the use of a stationary form of this model for quantitative analysis of postwar monetary business cycles. The nonstationarity that arises in the liquidity model also raises an important question about other monetary models in which nonneutralities are tied to money's medium of exchange role: When money's medium of exchange role changes, should we also expect the nonneutrality of money to change?

Our results also have implications for empirical studies of money and business cycles. In particular, our results provide a theoretical complement to the empirical literature that has studied changes in the effects of money shocks over time. This literature largely concludes that the nonneutrality of money has not changed dramatically over the postwar period. This view is consistent with the predictions of the sticky price model, but is harder to reconcile with the predictions of the basic liquidity model, which indicate a very distinct type of instability in the nonneutrality of money over this period.

We can draw two conclusions from the view that the effects of money shocks have not changed much over time. One is that the nonneutrality of money in the postwar United States may largely be due to imperfect price adjustment rather than to the financial frictions associated with segmented markets. The other conclusion is that there may be an important connection between monetary nonneutralities and money's unit of account role, but perhaps no quantitatively important connection between nonneutralities and money's medium of exchange role. 


\section{Appendix}

In this appendix, we conduct some additional experiments in which we change parameters of the model and analyze how the nonneutrality of money changes.

Two sets of parameters govern money demand for households and firms in the liquidity and sticky price models. The share parameters $\{\gamma, \eta\}$ govern the fraction of goods (for households) and the fraction of inputs (for firms) that must be purchased with cash. The curvature parameters $\{\theta, \psi\}$ govern the elasticity of substitution between cash and credit goods (for households) and inputs (for firms). Our three experiments consist of exogenously changing these parameters and assessing how these changes affect the stochastic steady states of the two models. In the first experiment, we change the share parameter and hold fixed the curvature parameters. In the second experiment, we change the curvature parameters and hold fixed the share parameters. In the third experiment, we hold fixed both of these parameters and change the average growth rate of money, which changes the average nominal interest rate. Thus, the first two experiments assess the effects of shifts in the demand for money by firms and households, while the third allows us to analyze the effects of movements along the money demand schedule for firms and households. ${ }^{20}$

We continue to use Cobb-Douglas preferences and the two-state i.i.d. money growth process. We use a nonlinear equation solver to compute the equilibrium, and we choose a termination criterion that the maximum deviation of any equation is no greater than e-04 percent.

\section{Experiment 1: Changes in Cash/Credit Share Parameters}

Tables A1-A3 present the percentage standard deviations of output, velocity, and the ratio of household money holdings to firm money holdings for different combinations of the share parameters that govern the fraction of cash goods purchased by households, $\gamma$, and the fraction purchased by firms, $\eta$. We consider changes in the parameters over the range from 0.1 to 0.9 . Thus, the combination $\gamma=0.9, \eta=0.9$ corresponds to an economy in which 90 percent of goods and services for both households and firms must be purchased with cash. To

\footnotetext{
${ }^{20}$ It turns out that changing the preference parameters $\beta, \sigma$, and $\zeta$ does not affect the results. To conserve space, we don't report these results.
} 
facilitate comparisons, we normalize the standard deviations of output and velocity relative to their values at the parameter configuration $\gamma=0.5, \eta=0.5$. Thus, all entries in the cell $\gamma=0.5, \eta=0.5$ are 1 , and all other cells measure changes relative to that cell. In this experiment, we assume that the elasticity of substitution for cash and credit goods is the same for households and firms. We choose a value for the parameters $\{\theta, \psi\}$ of 0.95 . We discuss the implication of this parameter choice for the interest elasticity of money demand below.

For the liquidity model, we find a roughly linear relationship between changes in the composition of money holdings and changes in the nonneutrality of money. For example, an increase in this ratio from $1(\gamma=\eta=0.5)$ to about $10(\gamma=0.9, \eta=0.1)$ increases the normalized percentage standard deviation of output from 1 to about 10. Analogously, a decrease in this ratio from $1(\gamma=\eta=0.5)$ to about $0.1(\gamma=0.1, \eta=0.9)$ reduces the normalized percentage standard deviation of output from 1 to about 0.1 .

For the sticky price model, the nonneutralities are basically invariant to changes in either or both of the share parameters between 0.1 and 0.5. For example, comparing the stochastic steady state at $\gamma=0.1, \eta=0.1$ to that at $\gamma=0.5, \eta=0.5$, we observe that velocity rises by over 400 percent, but the real effect of a money shock increases by only 3 percent. We note some sensitivity of the nonneutrality to share parameter changes between 0.5 and 0.9 , however. Comparing the stochastic steady state at $\gamma=0.5, \eta=0.5$ to that at $\gamma=0.9, \eta=0.9$., we observe an increase in velocity of close to 100 percent and an increase in the real effect of a money shock of about 25 percent. Moreover, a closer examination indicates that the sensitivity of a money shock to changes in the share parameters is highly nonlinear - much of the increase in the nonneutrality occurs in the neighborhood of $\gamma=0.9$, $\eta=0.9$. This suggests that a value of $\theta=0.95$ is in the invariant range for 0.1 , but is outside this range for $\gamma$ near 1 . Thus, the range for $\theta$ depends on the share parameter $\gamma$.

Why is the range varying? We find that the range varies because both $\theta$ and $\gamma$ determine the interest elasticity of money demand and that this is a key object in this model. It turns out that reducing the share parameters increases the interest elasticity, because the CES functions that aggregate cash and credit goods become less concave in credit goods. For example, with $\theta=\psi=0.95$ and both share parameters equal to 0.9 , the interest semi- 
elasticity of money demand is only about -0.005 . Around this point, reductions in the share parameters lead to increases in the real effect of a money shock. Raising the share parameters to 0.5 raises the semi-elasticity to about -0.03 , and raising the share parameters to 0.1 raises the semi-elasticity further to -0.05 . At these higher semi-elasticities, we find that the real effect of a money shock is invariant to changes in money demand. We find that for interest semi-elasticities above -0.01 , the nonneutrality of money is basically insensitive to changes in the share parameters.

\section{Experiment 2: Changes in Cash/Credit Curvature Parameters}

In this experiment, we vary the curvature parameters that govern the elasticity of substitution between cash and credit goods for households, $\theta$, and firms, $\eta$, and hold fixed the share parameters at 0.5. Tables A4-A6 present the percentage standard deviations of output, velocity, and the ratio of household money holdings to firm money holdings. We

choose $0.8,0.9$, and 0.99 . With both share parameters fixed at 0.5 , these values correspond to money demand interest semi-elasticities that range between -0.007 , which tends to be very low relative to estimates, and -0.19 , which exceeds most estimates. As in Tables A1-A3, the standard deviations of output and velocity are normalized. In this case, they are normalized relative to their values at the parameter configuration $\theta=0.9, \psi=0.9$.

The main finding for the liquidity model in this experiment is identical to that in the share parameter experiment: parameter changes that affect the ratio of household cash to firm cash have roughly linear effects on the real effect of a money shock, while symmetric changes that leave this ratio constant have virtually no effect on the nonneutrality of money in this model.

The results for the sticky price model in this experiment are also similar to those in the share parameter experiment. Increases in the interest semi-elasticity of either household or firm money demand from about -0.007 to about -0.19 results in a small increase in the real effect of a money shock.

\section{Experiment 3: Changes in the Average Growth Rate of Money}

We now examine the effects of one monetary policy change on the real effect of a money shock in these models: differences in the average growth rate of money, which lead 
proportionally to differences in the steady-state inflation rate. Changes in the inflation rate change the opportunity cost of holding money. In our model, an increase in the average inflation rate leads households and firms to substitute out of cash goods into credit goods, which raises velocity. The extent to which velocity increases depends on the elasticity of substitution between cash goods and credit goods for households and firms. Recall that these elasticities are governed by the curvature parameters $\theta$ and $\eta$ and the share parameters $\gamma$ and $\eta$. Tables A7-A9 present the percentage standard deviations of output and the ratio of household money to firm money for both models with an average money growth rate of 8 percent (high inflation) and an economy with an average money growth rate of 2 percent (low inflation). We present the percentage standard deviation of output for the high inflation case relative to the low inflation case. We examine different combinations of the curvature parameters $\theta$ and $\psi$, and we keep the share parameters fixed at 0.5 . When we analyze alternative combinations of the curvature parameters, we find that the interest elasticity of money demand between firms and households is unequal. Thus, changes in the inflation rate will lead to changes in the ratio of household money to firm money.

Our findings for the liquidity model are nearly identical to those in the technology experiments: changes in the ratio of household money to firm money brought about by different elasticities of substitution lead to nearly proportional changes in the percentage standard deviation of output. We find that the real effects of a money shock in the sticky price model are insensitive to changes in velocity or the composition of money holdings brought about by higher inflation. 


\section{References}

Alvarez, Fernando, and Andrew Atkeson. "Money and Exchange Rates in the GrossmanWeiss-Rotemberg Model," Journal of Monetary Economics 40 (December 1997): 619640.

Ball, Laurence, and David Romer. "Are Prices Too Sticky?" Quarterly Journal of Economics 104 (August 1989): 507-24.

Barnett, William A.; Edward K. Offenbacher; and Paul A. Spindt. "The New Divisia Monetary Aggregates," Journal of Political Economy 92 (December 1984): 1049-85.

Beehler, Paul J. Contemporary Cash Management: Principles, Practices, Perspective. New York: Wiley, 1978.

Blanchard, Olivier-Jean, and Nobuhiro Kiyotaki. "Monopolistic Competition and the Effects of Aggregate Demand," American Economic Review 77 (September 1987): 647-66.

Cecchetti, Stephen G. "Staggered Contracts and the Frequency of Price Adjustment," Quarterly Journal of Economics 100 (5), Supp. 1985, 935-59.

Cecchetti, Stephen G. "The Frequency of Price Adjustment: A Study of the Newsstand Prices of Magazines," Journal of Econometrics 31 (April 1986): 255-74.

Chari, V.V.; Patrick J. Kehoe; and Ellen R. McGrattan. "Sticky Price Models of the Business Cycle: Can the Contract Multiplier Solve the Persistence Problem?" Research Department Staff Report 217, Federal Reserve Bank of Minneapolis, 1996.

Christiano, Lawrence J. "Modeling the Liquidity Effect of a Money Shock," Federal Reserve Bank of Minneapolis Quarterly Review 15 (Winter 1991): 3-34.

Christiano, Lawrence J., and Martin Eichenbaum. "Liquidity Effects and the Monetary Transmission Mechanism," American Economic Review 82 (May 1992): 346-353.

Christiano, Lawrence J.; Martin Eichenbaum; and Charles Evans. "The Effects of Monetary Policy Shocks: Evidence From the Flow of Funds," Review of Economics and Statistics 78 (February 1996): 16-34. 
Cole, Harold L., and Lee E. Ohanian. "Money is Shrinking So Why Aren't Business Cycles?," Discussion Paper, Federal Reserve Bank of Minneapolis, (February 1997).

Cooley, Thomas F., and Gary D. Hansen. "The Inflation Tax in a Real Business Cycle Model," American Economic Review 79 (September 1989): 733-48.

Dotsey, Michael. "An Investigation of Cash Management Practices and Their Effects on the Demand for Money," Federal Reserve Bank of Richmond Economic Review 70 (September/October 1984): 3-12.

Fuerst, Timothy S. "Liquidity, Loanable Funds, and Real Activity," Journal of Monetary Economics 29 (February 1992): 3-24.

Fuerst, Timothy S. "Optimal Monetary Policy in a Cash-in-Advance Economy," Economic Inquiry 32 (October 1994): 582-96.

Goldfeld, Stephen M., and Daniel E. Sichel. "The Demand for Money," in Handbook of Monetary Economics, Volume 1, edited by Benjamin M. Friedman and Frank H. Hahn, Amsterdam: Elsevier Science, 1990, pp. 229-356.

Grossman, Sanford, and Laurence Weiss. "A Transactions-Based Model of the Monetary Transmission Mechanism," American Economic Review 73 (December 1983): 871-80.

Hall, Robert E., and N. Gregory Mankiw. "Nominal Income Targeting," in Monetary Policy, edited by N. Gregory Mankiw, Chicago: The University of Chicago Press, 1994, pp. $71-93$.

Judd, John P., and John L. Scadding. "The Search for a Stable Money Demand Function: A Survey of the Post-1973 Literature," Journal of Economic Literature 20 (September 1982): 993-1023.

Kashyap, Anil K. "Sticky Prices: New Evidence from Retail Catalogs," Quarterly Journal of Economics 110 (February 1995): 245-74.

King, Robert G., and Mark W. Watson. "Money, Prices, Interest Rates and the Business Cycle," Review of Economics and Statistic 78 (February 1996): 35-53. 
Leeper, Eric M.; Christopher A. Sims; and Tao Zha. "What Does Monetary Policy Do?" Brookings Papers on Economic Activity 0 (2), 1996, 1-63.

Lucas, Robert E., Jr. "Money Demand in the United States: A Quantitative Review," Carnegie-Rochester Conference Series on Public Policy 29 (Autumn 1988): 137-67.

Lucas, Robert E., Jr. "Liquidity and Interest Rates," Journal of Economic Theory 50 (April 1990): 237-64.

Lucas, Robert E., Jr., and Nancy L. Stokey. "Money and Interest in a Cash-in-Advance Economy," Econometrica 55 (May 1987): 491-513.

Mankiw, N. Gregory. "Small Menu Costs and Large Business Cycles: A Macroeconomic Model," Quarterly Journal of Economics 10 (May 1985): 529-38.

Mankiw, N. Gregory. and Lawrence H. Summers. "Money Demand and the Effects of Fiscal Policies," Journal of Money, Credit, and Banking 18 (November 1986): 415-29.

Porter, Richard D., and Ruth A. Judson. "The Location of U.S. Currency: How Much Is Abroad?" Federal Reserve Bulletin 82 (October 1996): 883-903.

Rotemberg, Julio J. "A Monetary Equilibrium Model With Transactions Costs," Journal of Political Economy 92 (February 1984): 40-58.

Schlagenhauf, Don E., and Jeffrey M. Wrase. "Liquidity and Real Activity in a Simple Open Economy Model," Journal of Monetary Economics 35 (August 1995): 431-61.

Sims, Christopher A. "Comments on Glenn Rudebusch's 'Do Measures of Monetary Policy Make Sense?'” Discussion Paper, Yale University, 1996.

Sims, Christopher A., and Tao Zha. "Does Monetary Policy Generate Recession?" Discussion Paper, Yale University, 1995.

Stock, James H., and Mark W. Watson. "A Simple Estimator of Cointegrating Vectors in Higher Order Integrated Systems," Econometrica 61 (July 1993): 783-820. 
Svensson, Lars E. O. "Sticky Goods Prices, Flexible Asset Prices, Monopolistic Competition, and Monetary Policy," Review of Economic Studies 53 (July 1986): 385-405.

Taylor, John B. "Staggered Wage Setting in a Macro Model," American Economic Review 69 (May 1979): 108-13.

Woodford, Michael. "Monetary Policy in a World Without Money," forthcoming, Review of Economics and Dynamics, 1998. 
Table A1

Normalized Variability of Output

Liquidity Model

\begin{tabular}{|l||l|l|l|}
\hline$\gamma \backslash \eta$ & .1 & .5 & .9 \\
\hline \hline .1 & 0.994 & 0.188 & 0.099 \\
\hline .5 & 5.280 & 1.000 & 0.525 \\
\hline .9 & 10.109 & 1.920 & 1.007 \\
\hline
\end{tabular}

Sticky Price Model

\begin{tabular}{|l||l|l|l|}
\hline$\gamma \backslash \eta$ & .1 & .5 & .9 \\
\hline \hline .1 & 1.031 & 1.026 & 1.004 \\
\hline .5 & 1.025 & 1.000 & 0.948 \\
\hline .9 & 1.006 & 0.946 & 0.804 \\
\hline
\end{tabular}

Table A2

Normalized Velocity

Liquidity Model

\begin{tabular}{|l||l|l|l|}
\hline$\gamma \backslash \eta$ & .1 & .5 & .9 \\
\hline \hline .1 & 5.290 & 1.684 & 0.955 \\
\hline .5 & 1.679 & 1.000 & 0.688 \\
\hline .9 & 0.949 & 0.686 & 0.523 \\
\hline
\end{tabular}

Sticky Price Model

\begin{tabular}{|l||l|l|l|}
\hline$\gamma \backslash \eta$ & .1 & .5 & .9 \\
\hline \hline .1 & 5.290 & 1.714 & 0.976 \\
\hline .5 & 1.651 & 1.000 & 0.694 \\
\hline .9 & 0.930 & 0.680 & 0.523 \\
\hline
\end{tabular}

Table A3

Ratio of Household to Business Money Holdings

Liquidity Model

\begin{tabular}{|l||l|l|l|}
\hline$\gamma \backslash \eta$ & .1 & .5 & .9 \\
\hline \hline .1 & 1.000 & 0.189 & 0.099 \\
\hline .5 & 5.290 & 1.003 & 0.526 \\
\hline .9 & 10.081 & 1.920 & 1.007 \\
\hline
\end{tabular}

Sticky Price Model

\begin{tabular}{|l||l|l|l|}
\hline$\gamma \backslash \eta$ & .1 & .5 & .9 \\
\hline \hline .1 & 1.053 & 0.199 & 0.104 \\
\hline .5 & 5.580 & 1.056 & 0.554 \\
\hline .9 & 10.680 & 2.022 & 1.060 \\
\hline
\end{tabular}


Table A4

Normalized Variability of Output

Liquidity Model

\begin{tabular}{|l||l|l|l|}
\hline$\theta \backslash \psi$ & .80 & .90 & .99 \\
\hline \hline .80 & 1.000 & 1.019 & 1.522 \\
\hline .90 & 0.981 & 1.000 & 1.493 \\
\hline .99 & 0.655 & 0.668 & 0.997 \\
\hline
\end{tabular}

Sticky Price Model

\begin{tabular}{|l||l|l|l|}
\hline$\theta \backslash \psi$ & .80 & .90 & .99 \\
\hline \hline .80 & 0.920 & 0.948 & 1.011 \\
\hline .90 & 0.979 & 1.000 & 1.058 \\
\hline .99 & 1.111 & 1.111 & 1.115 \\
\hline
\end{tabular}

Table A5

Normalized Velocity

Liquidity Model

\begin{tabular}{|l||l|l|l|}
\hline$\theta \backslash \psi$ & .80 & .90 & .99 \\
\hline \hline .80 & 0.981 & 0.990 & 1.184 \\
\hline .90 & 0.990 & 1.000 & 1.197 \\
\hline .99 & 1.185 & 1.199 & 1.495 \\
\hline
\end{tabular}

Sticky Price Model

\begin{tabular}{|l||l|l|l|}
\hline$\theta \backslash \psi$ & .80 & .90 & .99 \\
\hline \hline .80 & 1.035 & 1.044 & 1.221 \\
\hline .90 & 0.991 & 1.000 & 1.185 \\
\hline .99 & 1.133 & 1.146 & 1.427 \\
\hline
\end{tabular}

Table A6

Ratio of Household to Business Money Holdings

Liquidity Model

\begin{tabular}{|l||l|l|l|}
\hline$\theta \backslash \psi$ & .80 & .90 & .99 \\
\hline \hline .80 & 1.004 & 1.023 & 1.528 \\
\hline .90 & 0.985 & 1.004 & 1.499 \\
\hline .99 & 0.658 & 0.671 & 1.002 \\
\hline
\end{tabular}

Sticky Price Model

\begin{tabular}{|l||l|l|l|}
\hline$\theta \backslash \psi$ & .80 & .90 & .99 \\
\hline \hline .80 & 1.255 & 1.279 & 1.910 \\
\hline .90 & 1.094 & 1.115 & 1.666 \\
\hline .99 & 0.665 & 0.678 & 1.013 \\
\hline
\end{tabular}


Table A7

Relative Variability of Output

high inflation $(8 \%)$ /low inflation $(2 \%)$

Liquidity Model

\begin{tabular}{|l||l|l|l|}
\hline$\theta \backslash \psi$ & .80 & .95 & .99 \\
\hline \hline .80 & 1.014 & 1.148 & 3.038 \\
\hline .95 & 0.892 & 1.010 & 2.678 \\
\hline .99 & 0.332 & 1.010 & 0.991 \\
\hline
\end{tabular}

Sticky Price Model

\begin{tabular}{|l||l|l|l|}
\hline$\theta \backslash \psi$ & .80 & .95 & .99 \\
\hline \hline .8 & 1.008 & 1.007 & 1.002 \\
\hline .95 & 1.018 & 1.013 & 1.003 \\
\hline .99 & 1.019 & 1.014 & 1.003 \\
\hline
\end{tabular}

Table A8

Relative Velocity

Liquidity Model

\begin{tabular}{|l||l|l|l|}
\hline$\theta \backslash \psi$ & .80 & .95 & .99 \\
\hline \hline .80 & 1.041 & 1.104 & 1.411 \\
\hline .95 & 1.105 & 1.181 & 1.583 \\
\hline .99 & 1.422 & 1.593 & 3.152 \\
\hline
\end{tabular}

Sticky Price Model

\begin{tabular}{|l||l|l|l|}
\hline$\theta \backslash \psi$ & .80 & .95 & .99 \\
\hline \hline .80 & 1.041 & 1.096 & 1.349 \\
\hline .95 & 1.107 & 1.181 & 1.568 \\
\hline .99 & 1.425 & 1.593 & 3.153 \\
\hline
\end{tabular}

Table A9

Relative Ratio of Household to Business Money Holdings

Liquidity Model

\begin{tabular}{|l||l|l|l|}
\hline$\theta \backslash \psi$ & .80 & .95 & .99 \\
\hline \hline .80 & 1.001 & 1.141 & 3.018 \\
\hline .95 & 0.887 & 1.005 & 2.665 \\
\hline .99 & 0.331 & 0.376 & 0.999 \\
\hline
\end{tabular}

Sticky Price Model

\begin{tabular}{|l||l|l|l|}
\hline$\theta \backslash \psi$ & .80 & .95 & .99 \\
\hline \hline .80 & 1.007 & 1.141 & 3.038 \\
\hline .95 & 0.887 & 1.005 & 2.677 \\
\hline .99 & 0.331 & 0.376 & 1.000 \\
\hline
\end{tabular}




\section{Figure 1}

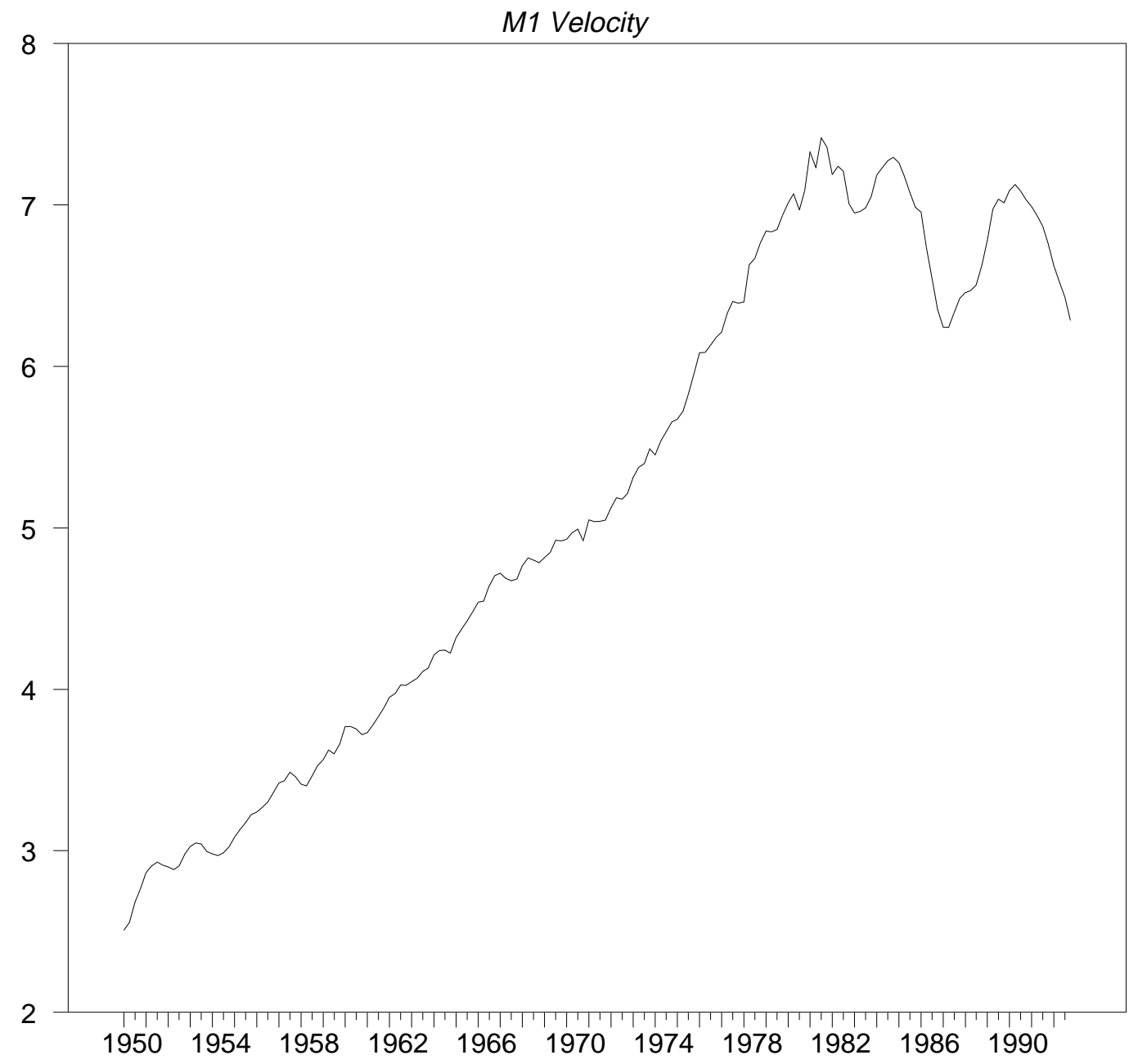

Figure 1: 


\section{Figure 2}

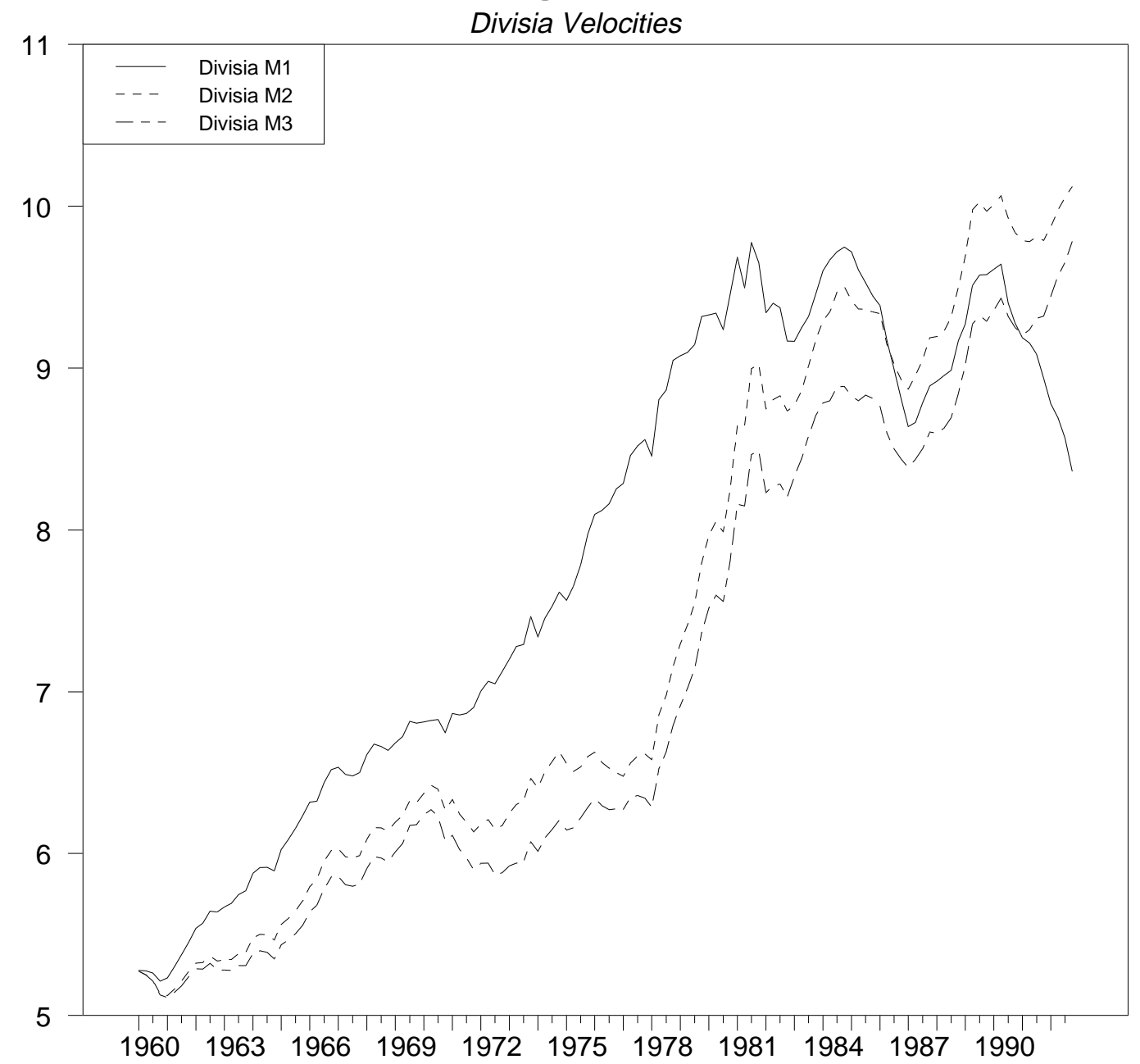

Figure 2: 


\section{Figure 3}

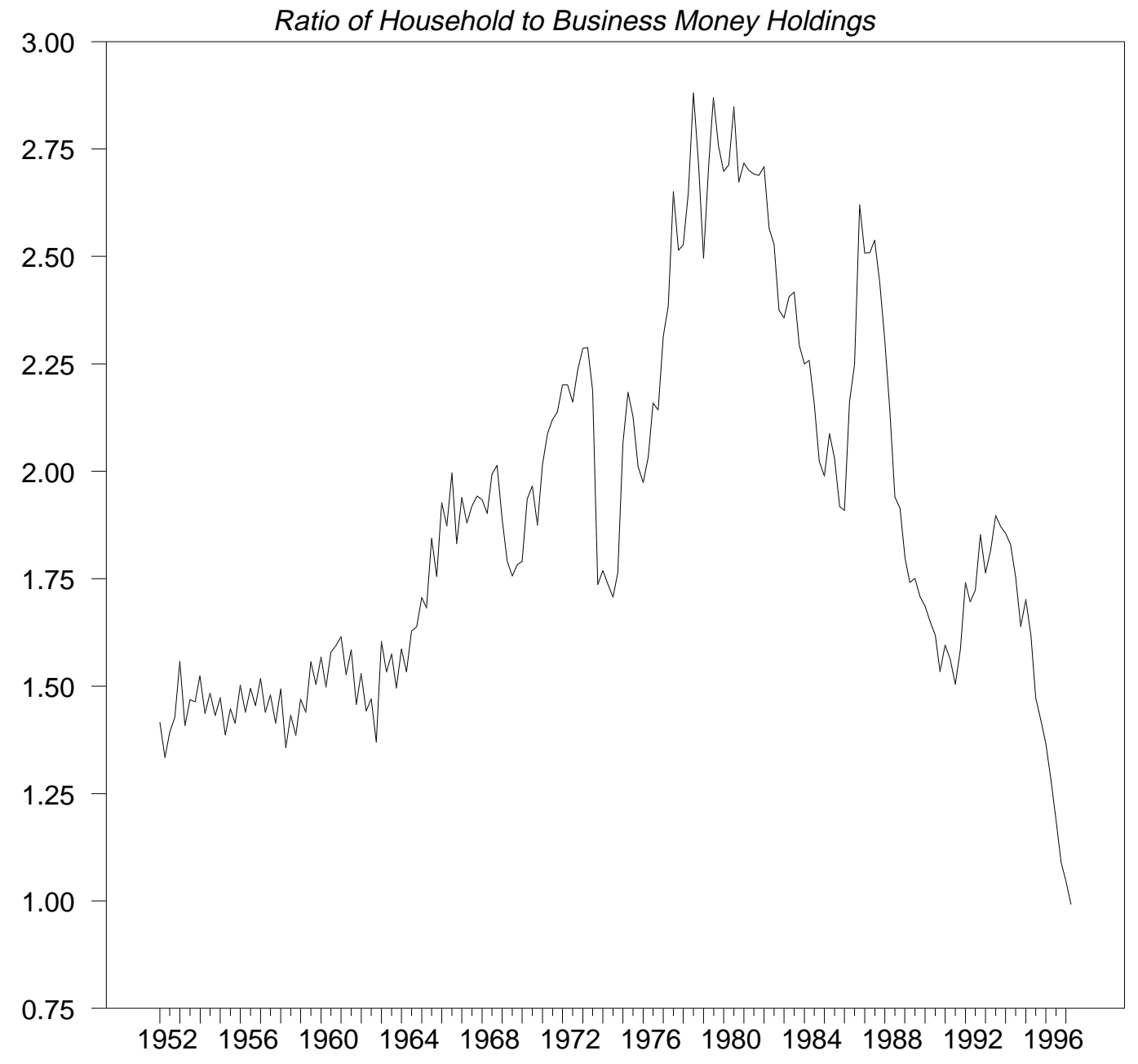

Figure 3: 


\section{Figure 4}

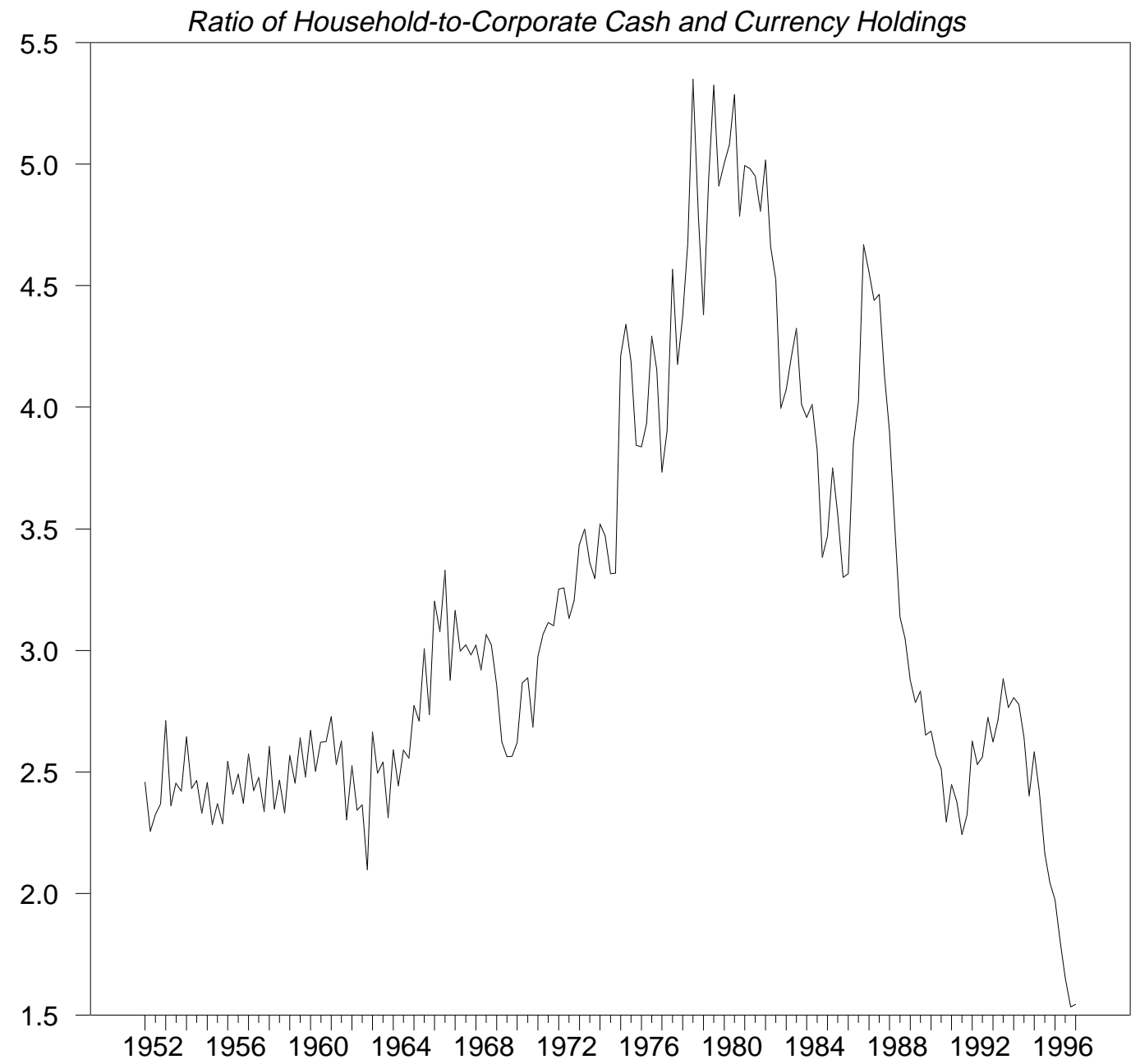

Figure 4: 


\section{Figure 5}

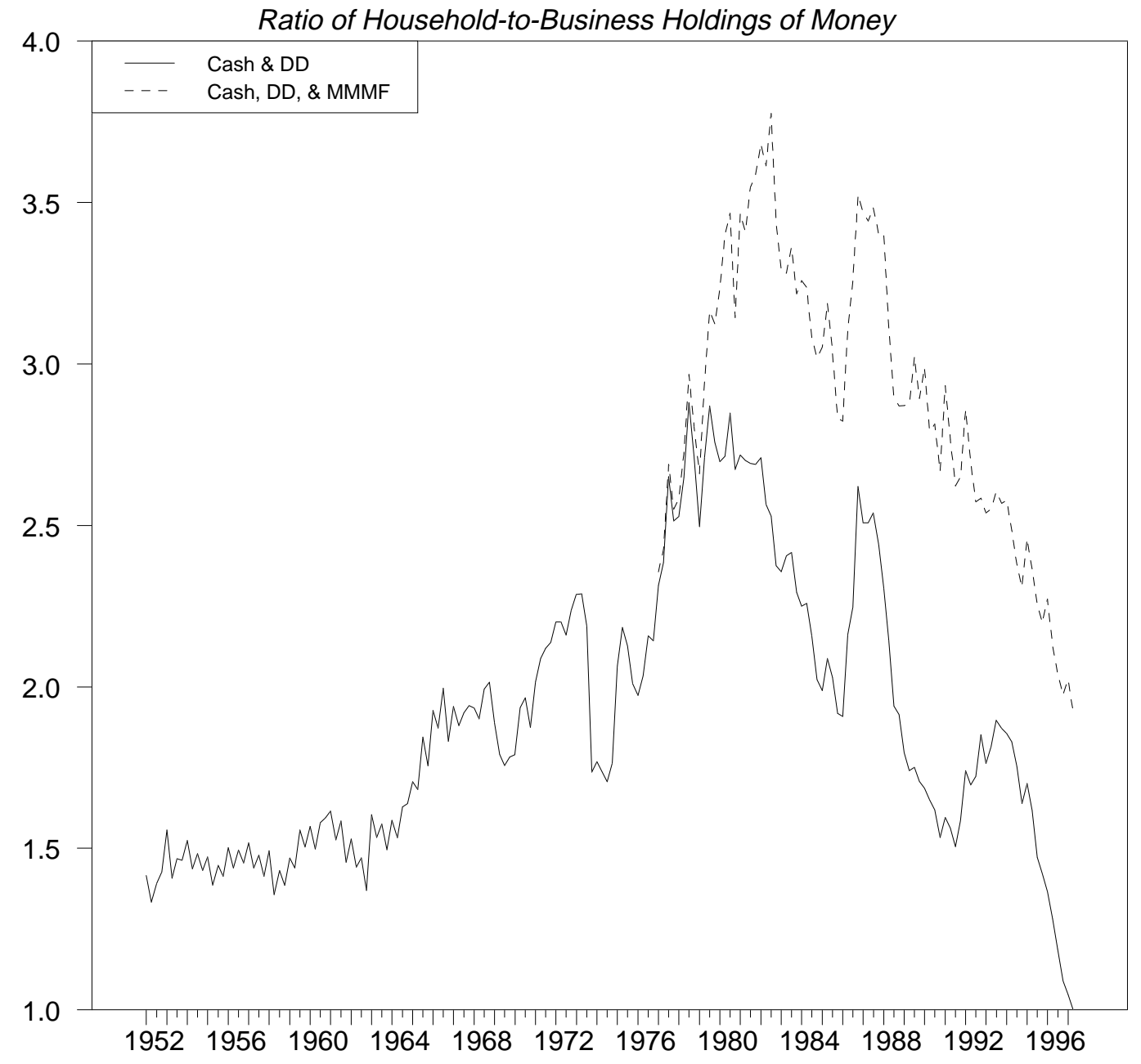

Figure 5: 